\title{
Many Plants Have Extrafloral Nectaries Helpful to Beneficials ${ }^{1}$
}

R. F. Mizell ${ }^{2}$

Most everyone is aware that flowers commonly produce nectar that is important in encouraging pollination as well as providing food for hummingbirds and insects. However, few people are aware of the extrafloral nectaries (EFN), nectar-producing glands physically apart from the flower (Fig. 1 and Fig. 2), that have been identified in more than 2000 plant species in more than 64 families. EFN glands may be located on leaf laminae (Fig. 3), petioles (Fig. 4), rachids, bracts, stipules, pedicels (Fig. 5), fruit, etc., and their size, shape and secretions vary with plant taxa. Ants often use EFN (Fig. 6 and Fig. 7) and many fascinating studies are available that report the interactions of ants with EFN and the plant's enemies, herbivores.

The composition of the gland secretion is about $95 \%$ sugar with the other $5 \%$ consisting of a wide array of amino acids and other important nutrients. EFN content differs from floral nectar, varies by taxa, and may or may not flow in a daily pattern. Two functions for the EFN have been hypothesized: as an excretory organ for the plant to rid itself of metabolic wastes or to attract beneficials for plant defense (Fig. 8). Of the plant species with EFN that have been studied, the majority of the results, although not all, have supported the plant defense function. It is well documented that many insects use EFN and it is easy to observe beneficial insects such as ladybird beetles feeding on EFN. Many species of ants are found in association with plants having EFN and are thought to be manipulated by the plant using its EFN.

Interestingly, a great many species of vines have EFN and the evolution and selection for EFN is hypothesized to occur as a direct result from the ants using the vines frequently as natural pathways into the forest canopy.

Passion flower, Passaflora spp., partridge pea, Cassia spp., hairy vetch, Vicia sp. and elderberry, Sambucus spp., are common Florida plants with large EFN on the leaves and/or stems that are easy to find. Most cultivars of peach (and Prunus spp. in general) have EFN on the leaves, although a few (e.g. 'GoldPrince' and 'JunePrince') do not. The occurrence of EFN appears to be controlled by a single gene in most plant species. EFN offer an important supplemental food source for beneficial insects, and too, some pest species (Fig. 9) particularly during extreme weather conditions such as drought and other times of the year when prey are scarce. EFN may be valuable if not critical

1. This document is one of a series of the Department of Entomolgy and Nematology, Florida Cooperative Extension Service, Institute of Food and Agricultural Sciences, University of Florida. Publication date: March 2004. Please visit the EDIS Web site at http://edis.ifas.ufl.edu.

2. Russell F. Mizell, professor, North Florida Research and Education Center, Institute of Food and Agricultural Sciences, University of Florida, Gainesville, FL 32611

The Institute of Food and Agricultural Sciences (IFAS) is an Equal Employment Opportunity - Affirmative Action Employer authorized to provide research, educational information and other services only to individuals and institutions that function without regard to race, creed, color, religion, age, disability, sex, sexual orientation, marital status, national origin, political opinions or affiliations. For information on obtaining other extension publications, contact your county Cooperative Extension Service office. Florida Cooperative Extension Service / Institute of Food and Agricultural Sciences / University of Florida / Larry R. Arrington, Interim Dean 
components in the ecology of landscapes. A great many opportunities exists to further our understanding of EFN in landscape systems as much remains to be understood about the roles EFN play.

\section{Some Plant Families with EFN}

Liguminaceae, Rosaceae

Mimosaceae, Euphorbiaceae

Bignoniaceae, Compositae

Malvaceae, Salicaceae

Curbubitaceae, Caprifoliaceae

Asclepiadaceae, Liliaceae

Caesalpiniceae, Convolvulaceae

Papilionaceae, Fabaceae

\section{Some Species with EFN in Florida}

Abutilon (Indian mallow)

Ailanthus altissima (silk tree)

Allamanda nerifolia

Aphelandra (tropical herb or shrub)

Callecarpa (beauty berry)

Campsis radicans (trumpet creeper)

Cassia fasciculatus (partridge pea)

Catalpa speciosa (indian bean)

Cattleya orchids

Cissus rhombifolia (ivy)

Clerodendron (tube flower)

Costus (spiral ginger)

Crotolaria striata

Croton spp.
Curcurbits

Dioscorea sp. (air potato)

Fraxinus sp. (ash)

Fritillaria sp. (N. Am. lily)

Gossypium hirsutum (cotton)

Helianthus sp. (sunflower)

Helionthella quinuenervis (W. N. Am. herb)

Hibiscus sp.

Hoya sp.

Impatiens balsamina

Ipomoea pandurata (morning glory)

Osmanthus sp. (devil weed)

Oxypetalum sp. (S. Am. shrub)

Paeonia sp. (peony)

Passiflora incarnata (passion flower)

Pennisetum sp. (tropical grass)

Phaseolus sp. (beans)

Polygonium sp. (knot, smartweed)

Prunus spp.(peach) most of 431 species have

Pteridium aquilinum (bracken)

Ricinus communis (castor bean)

Robinia pseudoacacia (black locust)

Salix sp. (willow)

Sambucus nigra (elderberry)

Smilax macrophylla (green briar)

Thumbergia grandifloria (blue trumpet vine)

Viburnum opalus, V. americanum

Vicia sativa (vetch) 
Vigna unguiculata (cowpeas)

\section{Location of Some EFN}

Ailanthus: leaf margins

Allamanda: leaf axils

Callecarpa: adaxial surface near veins at leaf base

Cassia: petiole

Cissus: stipule

Costus: outer surface of floral bracts

Crotolaria: flower stalk

Croton: petiole

Curcurbits: lamina, pedunular bracts, abaxial surface of calyx

Fraxinus: glandular trichomes on lower leaf surface

Gossypium: leaf or flower bracts

Helianthus: flower bracts and phyllaries

Hibiscus: sunken, elongate cavity part of midvein adaxial surface

Hoya: upper leaf surface

Impatiens: petiole and leaves

Ipomoea: lower leaf surface, petiole, pedicel just below junction with sepals

Osmanthus: glandular trichomes on lower leaf surface

Passiflora: petiole, bud and flower bracts

Phaseolus: on the cushion-like compressed lateral branches on the inflorescence axis

Prunus: distal part of leaf petiole/leaf blade

Pteridium: stipe and fronds

Ricinus: leaf and inflorescence

Robinia: stipules
Salix: leaves

Sambucus: stipules

Smilax: tiny, flattened on lower leaf surface

Thunbergia: sepals

Viburnum: lower leaf surface near petiole

Vicia: stipules

Vigna: stipules and inflorescence stalk

\section{References for Further Reading}

Bentley, B. L. 1977. Extrafloral nectaries and protection by pugnacious bodyguards. Ann. Rev. Ecol. Syst. 8:407-427

Pemberton, R. W. and N. J. Vandenburg 1993. Extrafloral nectar feeding by ladybird beetles (Coleoptera; Coccinellidae). Proc. Entomol. Soc. Wash. 95: 139-151.

Pemberton, R. W. and L. Lee. 1996. The influence of extrafloral nectaries on parasitism of an insect herbivore. Am. J. Botany. 83: 1187-1194.

Rogers, C. E. 1985. Extrafloral nectar: entomological implications. Bull. Entomol. Soc. Am. 31: 15-20.

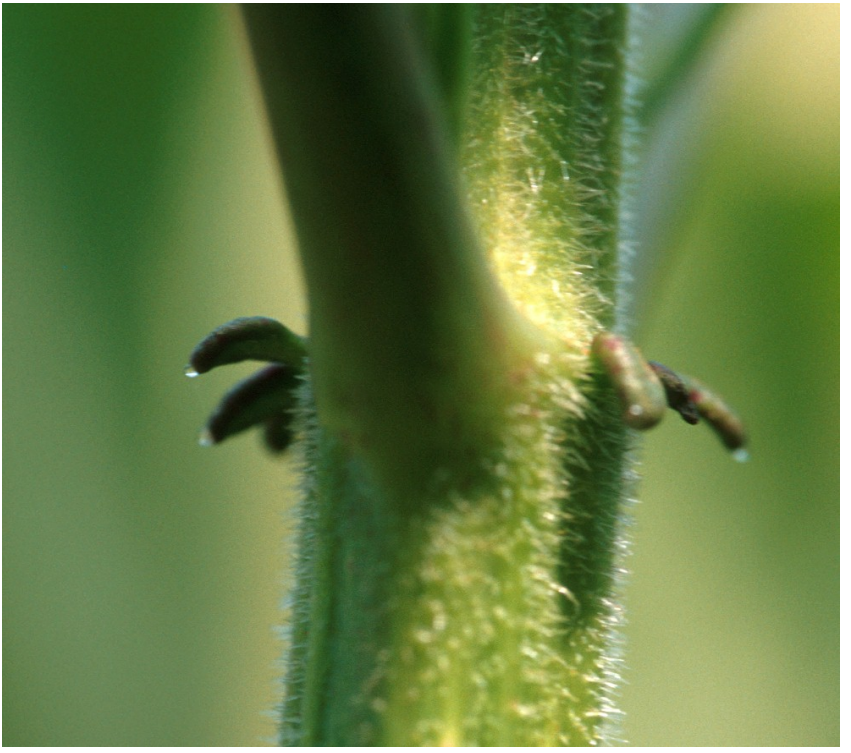

Figure 1. Extrafloral nectaries secreting nectar on the stems of young elderberry plants. 


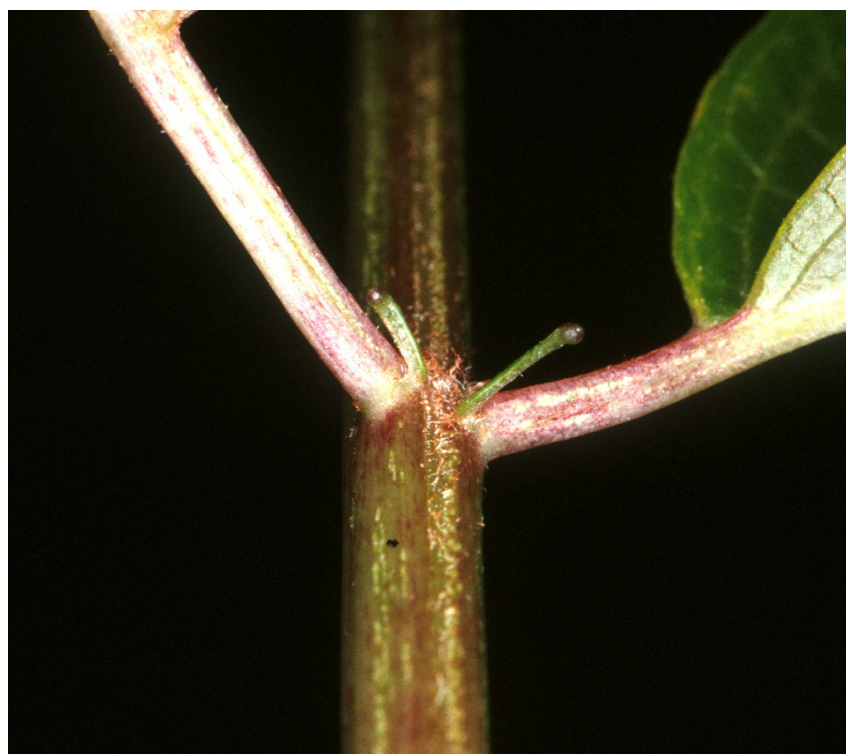

Figure 2. Extrafloral nectaries on stalked structures on elderberry leaves.

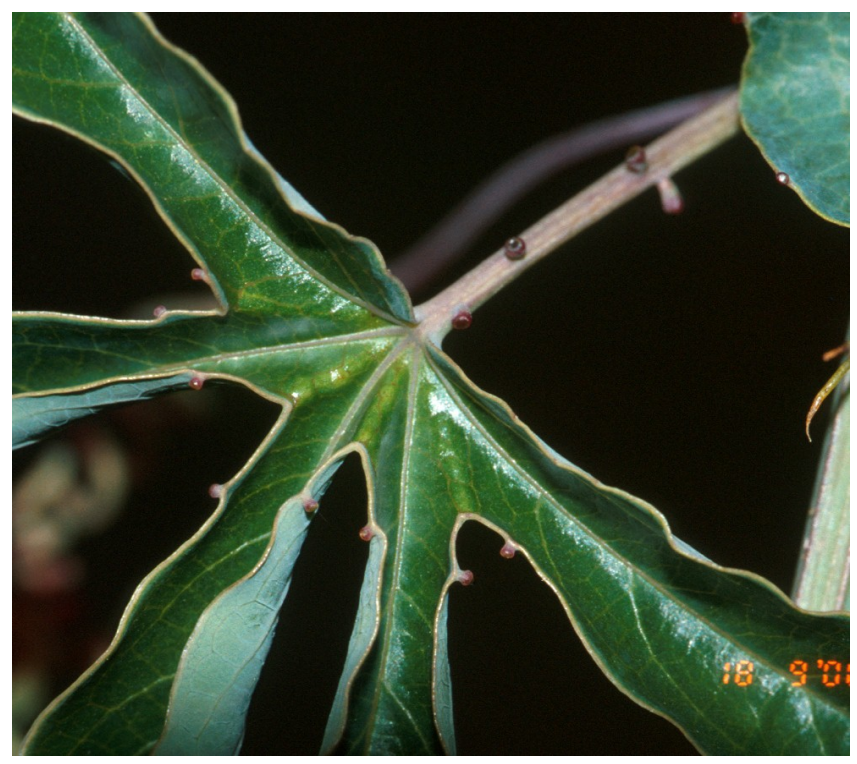

Figure 3. Extrafloral nectaries on the leaves of passionflower.

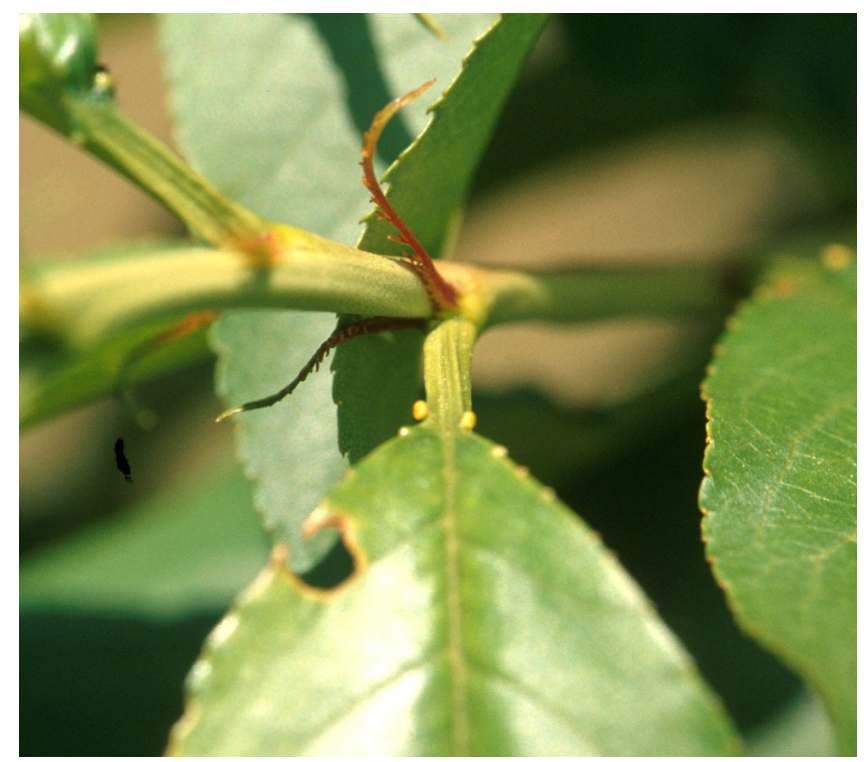

Figure 4. Extrafloral nectaries (lobes) on peach.

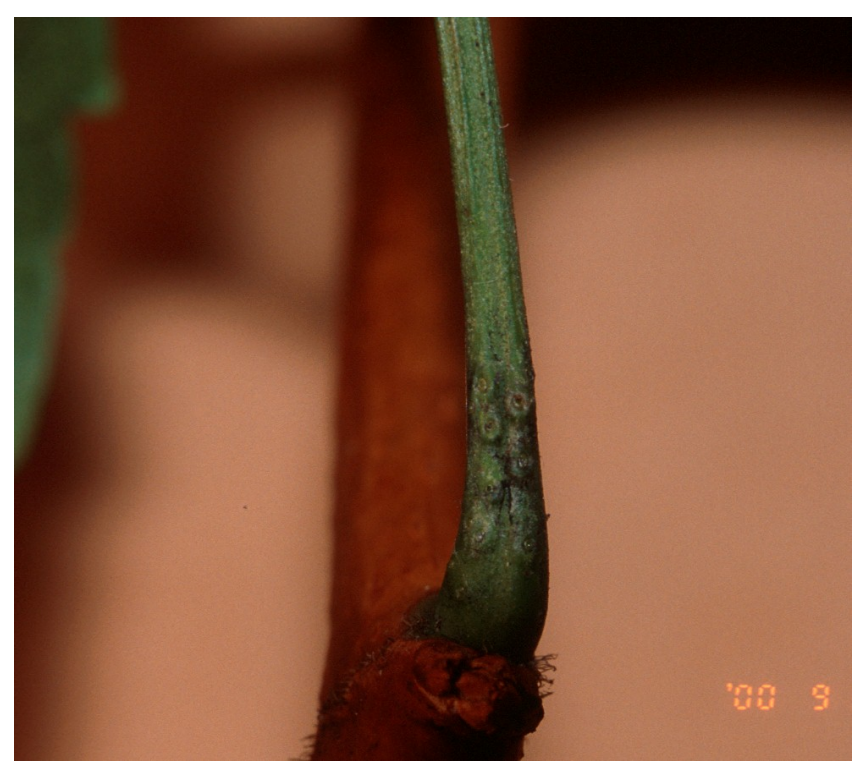

Figure 5. Extrafloral nectaries (pits) on the petioles of trumpet vine. 


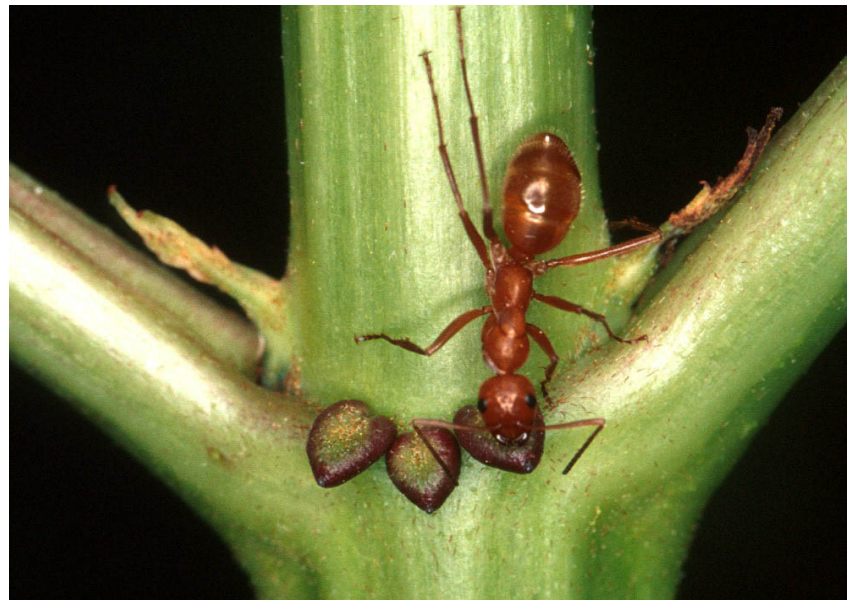

Figure 6. A large species of ant using the EFN of elderberry in north Florida.

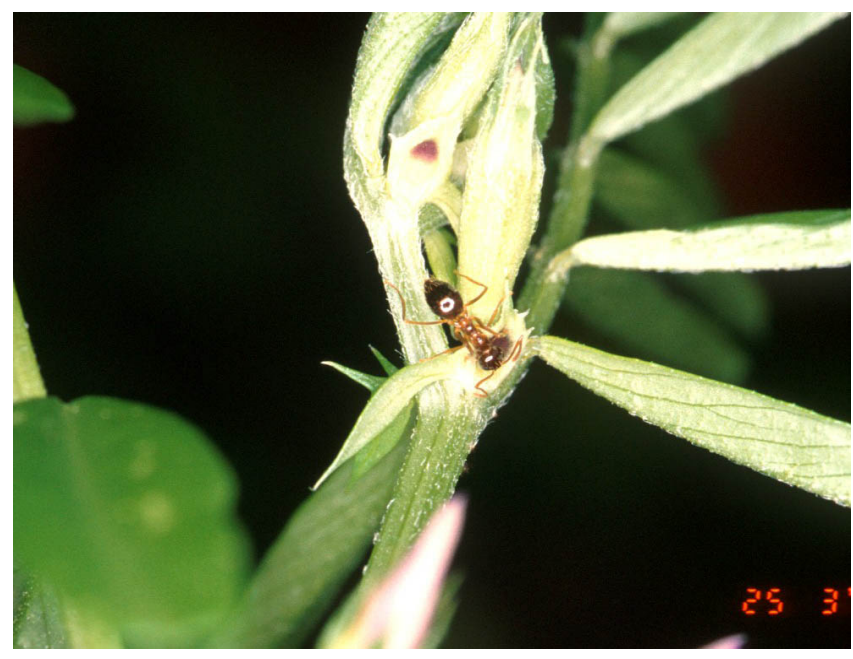

Figure 7. Extrafloral nectaries with visiting ant on hairy vetch.

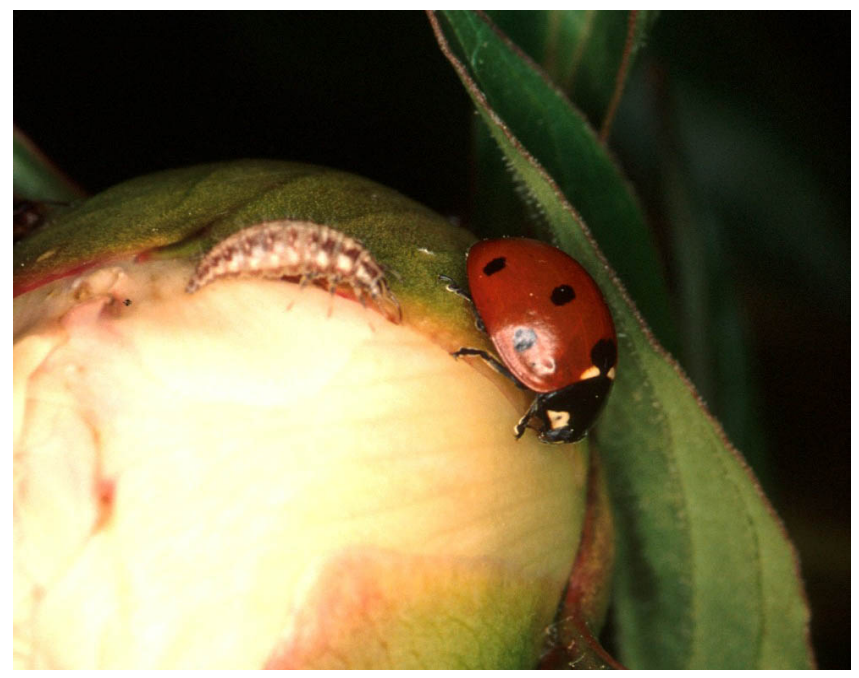

Figure 8. A ladybeetle, Coccinella septumpunctata and a lacewing larva feeding on the EFN on a flower bud of peony.

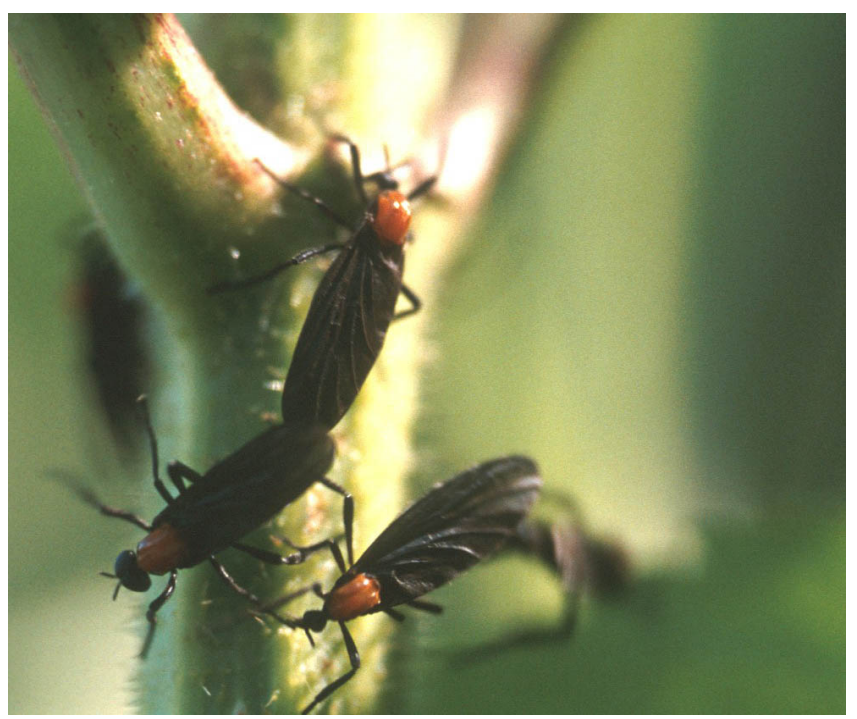

Figure 9. Lovebugs feeding on the EFN of elderberry. 